\title{
CONSTRAINTS OF MATH TEACHERS' IN CONDUCTING ACTION RESEARCH IN THE PHILIPPINES: RIGHTS ANALYSIS
}

\author{
${ }^{1}$ Paolo Nino Valdez \& ${ }^{2}$ Minie Rose Lapinid \\ ${ }^{1 \& 2}$ Bro. Andrew Gonzalez College of Education \\ De La Salle University Manila \\ ${ }^{1}$ Corresponding author:paolo.valdez@dlsu.edu.ph
}

\begin{abstract}
Purpose - This exploratory investigation examines the material and non-discursive constraints of Math teachers in conducting action research in the Philippines. It initially describes the contexts of participation of scholars situated in the periphery in knowledge production and teases out the apparent challenges faced in the successful conduct of research.
\end{abstract}

Methodology - Anchored on Lave and Wenger's concept of community of practice and legitimate peripheral participation, the study employs rights analysis as a means to determine the constraints of the respondents in doing action research. Additionally, it traces the mechanisms of power that reinforce and reproduce these challenges. Data was obtained from 13 mathematics teachers employed in different schools under the Manila Archdiocesan and Parochial Schools Association (Mapsa). These teachers have varying work experiences and are teaching different grade levels. The respondents were systematically sampled since they are part of an action research course under the master's program in teaching math offered by the university.

Findings - Based on the findings, it is argued that due to the disempowering material, social and political conditions of these teachers, they may be considered as part of a hierarchy of peripheral participation since they possess limited opportunities for academic socialisation in the conduct of action research. Finally, this paper draws implications for the improvement of research training in periphery contexts. 
Significance - With the increased interest in the socio-political dimension in the teaching and learning process, this work may be of interest to those engaged in conducting research training as well as other stakeholders in the academe to improve the conduct of action research in their respective educational institutions.

Keywords: Action research, community of practice, mathematics education, Philippine educational system, research training, rights analysis, teacher education.

\section{INTRODUCTION}

In teacher education programs, action research has become a viable option in institutions as it provides a contextual base for candidates to apply their learning inputs in their respective settings leading to critical reflection and practice (Poon, 2008; Dick, 2008). With the increased need for developing core competencies in the workplace, educational institutions are aggressively devoting a considerable amount of time and resources to integrating research training in their curricula. Broadly defined as a set of core competencies and skills in carrying out research work in a particular field, research training entails several key features (Pearson \& Brew, 2002):

1. The need to develop technical skills to conduct successful research in an area;

2. The capacity to develop research worthy of dissemination and consumption; and

3. The capacity of researchers to contribute to an educational institution's level of prestige in terms of expertise.

Recent scholarship indicates that action research has been a key activity among teacher-educators in promoting reflective practice (Burton \& Barlett, 2005). Defined as a recursive-reflective form of scholarly inquiry, action research concerns itself with critical and interpretive perspectives on classroom life (Carr \& Kemmis, 1986). For instance, Hagevik, Aydeniz and Rowell (2012) view action research as a productive activity for teachers to engage in critical inquiry, collaborative efforts and reflective thinking. Penney 
and Leggett (2005) believe that meaningful action research among teacher-educators can lead to continuous professional development. Through this, practitioners become more equipped to deal with concerns on the teaching and learning process by using organised inquiry. Though the benefits of action research are well documented, a vibrant strand of research lies on the inherent difficulties practitioners face when conducting this type of investigation. Departing from positivistic views of knowledge production, the influx of writings that acknowledge the political dimension embedded in scholars' work has its place in current thinking in the field. In the context of this investigation, doing action research does not only entail the successful identification of a problem, formulation and implementation of intervention and further investigation, but also imposes non-discursive demands on the part of the teacherresearcher. Specifically, this paper shares Canagarajah's (1996) view that scholars situated in the periphery need to contend with the relational and material requirements in conducting research and publications aside from the discourse requirements of scholarly work. Literature in this area has identified funding (Man, Weinkauf $\&$ Sin, 2004); policy and structural support (Salager-Meyer, 2008); and academic socialisation (Uzuner, 2008) as constant challenges among periphery scholars in conducting successful research work. Further, Tupas' (2011) identification of periphery scholars' difficulties in participating in processes of knowledge production are finely embedded in ideologies of economy, power and dominance. He furthers that the inversely proportional relationship between the population of the world and the contributions to research indicates the existing hegemony in knowledge production. Canagarajah (1996), in his account, emphasizes the paralyzing effects of material and procedural constraints in allowing scholars situated in the periphery to participate in knowledge production. For instance, the lack of a wide range and recent scholarly materials, absence of electricity or computer and photocopying facilities and efficient mailing services in Sri Lanka influences the discursive practices necessary for conducting research and publication. Similar to the aforementioned inputs, the Philippines' problems on competent research training can be attributed to lack of policies and support for teaching staff (Calma, 2009). Based on these related themes concerning our study, 
research therefore exists within a richly contested activity where power is constantly negotiated among members of a community. In Foucauldian terms, we trace the notion of power as a mechanism that resides not only in the products of doing research but also the in processes that underlie its development. For instance, the academic socialisation, material and structural resources available to the research student are part of a vast network of entities that contribute to the success/failure of research training in a university (Foucault, 1980). Considering these inputs, the aim of this paper therefore is to determine the constraints among math teachers in the Philippines to successfully conduct action research in their respective settings. Our investigation is anchored on a politically-oriented strand in scholarship. From this perspective, the investigation is located in terms of determining the material and other non-language related (Salager-Meyer, 2008) obstacles for successful conduct of action research. It also attempts to determine the possible mechanisms of power at work in maintaining these constraints.

\section{THEORETICAL/ANALYTICAL FRAMEWORK}

This investigation is anchored on the concepts of communities of practice (henceforth, CoP); legitimate peripheral participation (henceforth, LPP); and rights analysis (henceforth, RA). In understanding the non-discursive constraints in conducting research, one has to determine the extent to which participants engage with CoP and LPP (Lave \& Wenger, 1991). These concepts highlight the importance of participants' agency in developing themselves as legitimate participants in the profession. This means that experience and practice are key elements for practitioners to become prominent members of a specific professional community. Specifically, to gain experience, practitioners must constantly negotiate, reconstitute and appropriate their resources (both material and otherwise) to gain legitimate participation in this endeavor. However, there are some problems with the CoP and LPP frameworks in accounting for notions of power. Boylan (2010) emphasizes that power relations in the context of the math classrooms cannot simply be an asymmetrical activity between teacher and student. Rather, he believes that other 
external forces, such as the curriculum, policies and practices in school play a role in the regulation of agency among participants. Moreover, he asserts the importance of accounting for power in the participants' setting where resources, both abstract and material, are reconstituted in meaningful ways within spaces of engagement. Considering this apparent shortcoming, we considered the analytical tool of RA espoused by Benesch $(1999 ; 2001)$ to account for the mechanisms of power that reinforce these constraints. Departing from Benesch's perspective, we see that RA is a tool for determining the political, social or ideological conditions of schools in relation to the facilitation of effective or ineffective teaching and learning. Moreover, RA is an analytical tool that allows investigators to trace the aforementioned conditions to help practitioners and students to create spaces for engagement to improve their teaching-learning conditions (Valdez, 2012).

Coupled with Needs Analysis, RA was done in an English for Academic Purposes course to determine how power is articulated in schools through requirements imposed by different levels of the organization (department, college, university). Moreover, it was able to determine the impact of these requirements on the teacher's implementation and students' reception of lessons which calls for more socially conscious approaches in course design. RA aligns itself to the present research such that it does not simply identify the non-discursive obstacles of teachers in conducting action research, but also how power is exercised in their spaces of participation. More importantly, RA affords researchers to seek opportunities for change through negotiation of spaces for engagement.

In the case of the present investigation, employment of RA contributes to a political stance in course design in order for students to truly achieve their purposes in the program.

\section{CONTEXT OF THE PROGRAM}

The study was conducted in De La Salle University, Manila, Philippines. Aiming to address its goal of providing quality education through innovative programs, it offers the St. La Salle Teacher 
Education Program (henceforth, STEP) as a means to enhance teachers' professional development. Specifically, unlike other regular graduate degree offerings, the STEP program is a hybridextension program that allows students to finish their master's degree in one and half years. Operationally defined, the hybrid-extension program entails students to take the required number of units leading to a non-thesis degree through a compressed schedule ${ }^{1}$. Aside from the face-to-face consultation and class discussions, the Integrated Virtual Learning Environment (henceforth IVLE) of the university is used to manage coursework to facilitate instruction and learning on scheduled online sessions. Also, the students enjoy full tuition scholarships as part of the institution's thrust to extend its services to underprivileged sectors of society.

\section{PARTICIPANTS}

The participants are 13 basic Mathematics education teachers from the Manila Archdiocesan and Parochial Schools Association (MAPSA). These teachers are enrolled in the Action Research Methods and Writing courses offered in the Master of Teaching Mathematics program of the university. Briefly, the Action Research Methods is a 3-unit introductory course in educational research. Students enrolled in this course learn the various methods and procedures for conducting an action research, starting from problem identification, searching for and synthesising the literature and designing and implementing an empirical study in their field of specialisation. The Action Research Writing is another 3-unit course where students learn to apply the various methods and procedures for conducting an action research, starting from problem identification, searching for and synthesising the literature, and designing and implementing an empirical study in their field of specialisation. Further, students conceptualise and design their research proposal, and are required to present it and be critiqued by peers in class.

${ }^{1}$ Pseudonyms have been used for the respondents in the study. Likewise, for space considerations in the preparation of the article, responses are translated from Filipino to English. 


\section{METHODOLOGY}

Upon obtaining written consent from the participants, individual semi-structured interviews and focus group discussions were conducted. Four rounds of interviews were done during weeks $8 \&$ 9 of the term while focus group discussions were conducted on the 10th and 11th weeks.

In addition, transcription of the data and identification of appropriate themes were done. In order to address the aims of the research, the following points for discussion were raised: Their life history in terms of induction in the profession; their teaching context and initial experiences related to research and challenges posed in doing action research in their respective settings. Traingulation was also observed as school documents and reflective pieces of writing produced by the students were analysed to strengthen the findings.

In analysing the data, some principles of grounded theory were applied (Strauss \& Corbin, 1998). Specifically, since the data may yield different insights, the "long table approach" was applied (Ho, 2013). This meant upon collection of the data, frequent re-reading of transcripts was done to generate themes through key words in the interviews and focus group discussions. In addition, content analysis of contexts related to the key words earlier identified was done to further classify the themes. Since the investigation is interpretive in nature, the researchers tapped validators - both external and the participants themselves - to validate the themes generated.

\section{RESULTS AND DISCUSSION}

Organising the data into themes, presented below are the different constraints faced by the respondents in conducting action research in their respective schools.

\section{Theme 1: Action Research in Policy, Problematic Practice}

A central concern raised among the respondents is the different requirements set by the respective administrations of their institutions and other external agencies for a variety of purposes which lead to the non-conduct of action research. 


\title{
Sub-theme 1: Action Research for Compliance Purposes
}

Since all the respondents come from private schools, one priority area for their institutions is to gain accreditation through external agencies. In particular, the Philippine Accrediting Association for Schools, Colleges and Universities (henceforth, PAASCU) is one agency that sets standards for determining the level of accreditation accorded to private educational institutions. Specifically, PAASCU examines different core areas, such as teaching, faculty development and fiscal and structural resources. In the context of the investigation, one facet in accreditation is the capacity for schools to conduct action research in the belief that this will result in reflective practice and improvement of the teaching-learning process. On the contrary, the findings suggest that the respondents' institutions seem to compel the faculty to conduct action research in order to comply with PAASCU requirements. Ding, one of the secondary math teachers, emphasizes the objectives of doing action research as strictly for compliance to PAASCU recommendations:

\begin{abstract}
"We do it because PAASCU needs to see it. I have been approached by our principal on different occasions about this considering that I am a subject area coordinator for math. Since we are all involved in the preparation of requirements for the PAASCU, doing action research entails involvement of my teachers in the department".
\end{abstract}

The aforementioned statement can be interpreted in two ways: First, institutions in the Philippines that offer basic education are simply confined to teaching and not engaging in research. Given this reality, basic education institutions do not have provisions in terms of policy or resources to allow teachers to conduct action research. Second, given that accreditation in the Philippines is done through evaluation of different core areas, action research seems to be interpreted by the respondents' institutions as an additional requirement to be complied with. These interpretations seem to index the reality that action research is done in the respondents' schools without any participation from teachers in terms of identification of problems, implementation of intervention or presentation of findings. Adam laments on the superficial treatment of action research in his school: 
"Action research is applicable [in our school] but not applied. I haven't encountered any forum nor heard of results of investigations done. Often times, we are asked to respond to many surveys which ask of the same thing, yet, we do not know what the data is for nor do we have any idea if research is conducted at all. All we hear is the implementation of new programs is effective but you still see students fail or struggling with our lessons".

Although Pearson and Brew (2002) rightly argue that action research in the context of accreditation enhances prestige of an institution, the present findings contradict the notion that the activity is a source of knowledge production and dissemination but is rather treated symbolically as an act of compliance.

\section{Sub-theme 2: Action Research for Institutional Control and Regulation}

A critical aspect of RA is the orientation of seeking practices enmeshed with power that operate within different sectors of an organization. Focault's (1980) concept of the biopower is instructive here as it demonstrates that agents within an organization comprise parts of a body. These parts then exercise certain forms of power that regulate and control an institution's constituents. Several practices have been cited by the participants as forms of control and regulation in the conduct of action research. First, action research is required among the participants prior to signing of the clearance. Anthony confesses on the controlling purpose of the institution to compel teachers to do action research:

"We have a research center in our school. At the end of the year (March), most of us (teachers) need to get our clearance signed. However, our director does not sign our clearance if we do not submit our action research contribution. The difficulty there is that some who do not do their part experience delays in receiving their salary for the month".

One constraint cited by the respondents is the strict monitoring of their activities to assure that they observe their schedules and 
prescribed tasks. For instance, Sherwin mentions the installation of cameras and biometric systems in his institution as a way for the administration to monitor staff attendance and activities. Likewise, his colleague, Chris, identifies that the school requires journaling for the principal to document reflection among the teachers. However, Chris expresses apprehensions on these practices as these indicate control:

\begin{abstract}
"Before, we used to have time cards for attendance. Now, we have biometrics and if you get to look upward, there's a camera. I mean, I think this is overkill. Even our journal entries. We need to submit it every week to our principal. We can actually narrate experiences or negative reflections about our condition but we need to defend it. It would seem to me that the school would want to pinpoint certain problems especially with school operations or poor performance of students as attributed to us teachers".
\end{abstract}

Canagarajah's (1996) identification of the relational dimension of non-discursive constraints in activities related to knowledge production seems to be applicable here since these may be interpreted as strategies which effectively limit spaces for engagement among teachers. These are typical policing strategies that exercise regulation and control aimed to promote accountability and transparency in the teachers' work. Although it would seem that they are not directly related to the conduct of action research, these measures seem to create tensions on the part of the participants.

\title{
Theme 2: Disempowering Conditions
}

Similar to other educational institutions in the periphery, debilitating conditions, such as inadequate material resources, overcrowded classrooms and tremendous workload have emerged as concerns by the respondents.

\section{Sub-theme 1: Tremendous Workload/Insurmountable Working Conditions}

Similar to teachers in the Philippine educational system, the respondents identified their demanding multifaceted duties and responsibilities as an obstacle to conducting action research. To 
illustrate, Raina, one of the elementary math teachers, elaborates on her daily schedule:

"My work starts at 7:00 am but I have to be at my class at around 6:45 since there is a flag ceremony. I have eight classes a day and each class is 40 minutes. So from 7:20 to 1:00 pm, I teach and the only break I have is 40 minutes. The problem is I couldn't really eat or rest during my break because since I am a class adviser, I also have to monitor my students to make sure they do not leave the room because they might get hurt or meet an accident. So when I have the last two classes, I am practically exhausted and hungry. After my classes, that's the time where I get to check papers, do my lesson plan and other paperwork in preparation for the next day. That's why even if I'm allowed to leave at 4:00, I stay beyond that-usually until 6:00 or 7:00 just to get the job done. Now that I am enrolled in the STEP program, my superiors had to compress my schedule since I need to go to class on Fridays and Saturdays. So all of my scheduled classes had to be compressed in just four days".

Aside from the demanding schedules assigned to the teachers, the respondents also identified factors, such extra-curricular activities, huge class sizes and limited facilities for teaching and learning as deterrents. Craig, one of the seasoned teachers in the group, articulates on the aforementioned points:

"Since I have been teaching in the [name of school] for 12 years now, our work seems to be getting more and more complicated. Aside from teaching four hours a day, dealing with paperwork, I also have two clubs to moderate, advisory duties for a class. This year our school is in the process of constructing an additional building so since we have limited space, we had to compress some sections. Our senior high school level used to have eight sections of 35-40 students. Now, we only have six with around 50-55 students each. Early in the school year, one of our computer teachers left so instead of getting a replacement, it was decided 
that the teaching load would be distributed among the teachers. I also have two hours of additional teaching a week because of that. The problem is that our computer lab is in the same room with the speech lab so what happens is that the English Language teacher and I are competing when delivering a lecture to make sure that our voices are heard by our classes".

The aforementioned statements are reflective of Agarao-Fernandez and De Guzman's (2005) observation of the contextual realities faced by teachers in the Philippines. They add that the problem of developing competencies in research for the improvement of teaching and learning could not be addressed due to crowded classrooms and several clerical and non-academic duties accorded to teachers. In the same vein, Benesch (1999) attributes this to the demands imposed on different levels of the institution which cascades downwards placing the teachers at the receiving end of these problematic realities.

\section{Sub-theme 2: Departmental Politics}

Contextualising this theme from a community of practice perspective, the teacher-respondents cited departmental politics as a deterrent in the conduct of action research. Emerging from the data are two patterns of this sub-theme. First, the "crab" mentality syndrome observed in Philippine culture, where other members of the community negatively challenge the legitimacy of an individual's capacity to succeed in undertakings. Elle describes her experience when she faced opposition among her peers in initiating an action research project:

Elle

"The high school department is required to do action research but we, at the elementary level are not. Though I wanted to do it but the problem is, some of my colleagues and those of the other departments would raise an eyebrow and ask "why me". Even the fact that I got the scholarship in the university raised some questions about why I got into the program. So, in order not to cause any tension, we might as well not do it". 
Considered as a junior faculty in her school, Elle's entry to the program and initiatives of conducting action research may be interpreted as acts of superiority among her peers, resulting in tensions in the work environment. As a compromise to maintain smooth interpersonal relations and avoid conflict, Elle's non-participation in the activity is a means to appease her colleagues and maintain the indifferent and oppressive status quo.

The second emerging pattern under the departmental politics theme is the apparent miscommunication between administration and faculty leading to unproductive practices, such as delays or disjointed initiatives. The statements below concretize this sub-theme:

\section{Edward}

"When we were preparing for accreditation, one colleague was tapped to coordinate the action research for our school. Though I don't understand why she hesitated to give instructions. Later, she revealed that she was just tapped by our administration to coordinate it but she was not sure on how to go about it. What happened is that the administration was expecting her to coordinate but at the same time, my colleague did not understand when and how this will be done. She even asked me if I could help her out by lending her my notes and sharing what I've learned here in the program".

Roy

"In our department, we are asked to do parts of the action research. Last year, I was just asked to do the introduction and that's it. But, I don't know what happened. We (teachers) never had a meeting on how to go about it and I have no idea on the results of the investigation".

From a community of practice perspective, the aforementioned statements hint at the absence of mutual engagement between administration and faculty in conducting action research. Specifically, 
the notion of a joint enterprise where members of a community contribute organically to the achievement of a goal is not observed (Lave \& Wenger, 1991). Moreover, this shows the uncommitted stance in achieving something ideal, such as a successful action research. As Calma (2010) emphasises, the success of research training does not lie only on the material resources but the capacity of institutions to focus on the academic socialisation of its staff. This entails dealing comprehensively with the processes that the teachers need to undertake in order to conduct action research successfully.

\section{Sub-theme 3: Lack of Budget/Facilities}

The third sub-theme illustrates the concern raised by the respondents on the lack or practical absence of material resources in the conduct of research. Owing it to limited budget of their schools allocated for physical facilities, the respondents believe that their income cannot accommodate additional expenses for doing action research. Elle mentions this dilemma:

Elle

"I'd really want to do this but we don't have budget for it. Our salary is quite meager and not enough to cover our basic needs. At school, our resources are limited, we would need to go to shops to access internet and printing facilities is limited. So teachers would rather spend their money on their grocery or family needs instead of doing this".

Similar to other studies, the absence of financial resources and facilities such as laptops, computer units, printers, photocopying machines and competent mailing services lead to the disempowerment of scholars situated in the periphery to conduct research (Canagajah, 1996; Salager-Meyer, 2008; Tupas, 2011; Uzuner, 2008). Reflective of the findings above, the present conditions of teachers of the Philippine educational system indicate their meager earnings which are much lower compared to their professional counterparts. As identified by the respondent, since she could not afford to spend money on facilities for research, opting to conduct research is deemed difficult since she needs to allocate her finances for personal needs. 
Drawing on the findings, several points are apparent. First, the teachers' constraints in conducting action research are not only confined to the demands in terms of conceptual and procedural demands of the courses taken in the STEP program but also to the unique socio-political and material conditions of their own settings. Second, the findings indicate that action research is not done as it does not seem to actualize its true purpose of improving teaching and learning. Rather, it is embedded in the teachers' work as a form of regulation, control and compliance on the part of their institutions, which in turn are also compelled to meet standards imposed by accrediting agencies. Similar to Benesch's (1999) investigations of power relations in EAP classes, the mechanisms of power at work emanate from different levels of the organisation which constrain the participants' conduct of action research. Third, from a community of practice perspective (Lave \& Wenger, 1991), it would seem that the conduct of action research is constrained by the teachers' apparent disjunction with their colleagues due to institutional politics. This leads to disengaged and uncollaborative practices to avoid tensions among the respondents and their peers. In addition, the findings actualize the notion that non-discursive constraints are relational in nature as all of these conditions contribute to the constraining spaces for teachers to participate in knowledge production (Canagarajah, 1996). From a larger scale, the interrelated themes that emerged from the data suggests that the constraints in the conduct of action research may be typified as part of a hierarchy of peripheral participation in a community of practice. In keeping with Lave and Wenger's (1991) concept, the teacher-respondents may be considered as participants situated at the bottom of the hierarchy as their participation is constrained by a number of factors. Since they have only started pursuing graduate degrees in the STEP program, their exposure in the conduct of action research in educational settings may be considered as limited (Calma, 2010). Specifically, the present contexts of the respondents do not present opportunities for doing action research because aside from material and other constraints, their respective schools do not generally consider research as a priority activity in their agenda. These conditions may be explained in terms of their institutions' classification as private basic education schools which draw funds primarily from tuition and other income generating activities and are mainly used for staff remuneration and facilities/ resources (James, 1991). This is in stark contrast to faculty of higher education institutions in the Philippines which have appropriate funding and structural support to conduct research (Calma, 2009). 
The non-prioritisation of research in their institutions' agenda also influences the opportunities for academic socialisation. This can be explained by the observation of indifference or even negative reactions among the participants' colleagues towards conducting action research. These points therefore lead to the position that the teacher-respondents' difficulties lie on their inherent difficulty in negotiating their repertoires of engagement (Lave \& Wenger, 1991). Specifically, their capacity to mutually engage with their peers, share resources and promote accountability in doing action research is greatly hampered since the activity is not deemed important in their community. Extending Tupas' (2011) and Canagarajah's (2006) arguments on the conduct of research embedded in unequal global structures, scholars in the periphery do not only compete with their center/western counterparts in participating in knowledge production through research and publications, but also, periphery scholars compete among themselves due to their varying levels of research training, material and structural support and opportunities for participation. Relating the findings to the present context of the Philippine educational system, ideologically, action research is viewed from the outside - specifically, by administrators and accrediting agencies - as a naturalised activity, since they are situated much higher in the hierarchy of participation. On the other hand, the teachers view it as a "deviant", "educationally elite" enterprise that requires great effort on their part as it disrupts their ever demanding workload as well as their relations with their colleagues. Situating the findings from a Foucauldian perspective, Blommaert (2010) asserts that studying the impact of globalisation in practices in different domains requires nuanced accounts of deviation from naturalised practices as these open opportunities for investigating power relations. This means that though the teachers acknowledge the value of doing action research, the requirements imposed at different levels (external agencies-administration-colleagues) coupled with material inadequacies, and political climate of their local settings, create insurmountable conditions for the conduct of the activity.

\section{CONCLUSION}

Reflexively engaging these findings, several conclusions and implications are apparent. The notion of learner-centeredness appears to be a common buzzword among institutions of higher 
learning - leading to the development of "innovative" programs that intend to benefit learners in applying inputs in practice. However, as demonstrated in this investigation, educators, specifically course designers, would need to grapple with the reality that learners do not only contend with demands imposed by the program but also by the non-discursive and material constraints in their respective settings. Moreover, the mechanisms of power outlined in this study show the reinforcement and reproduction of these constraints leading to the teachers' disempowerment in applying action research in their own respective schools. Although it is understood that the university's attempt to efficiently manage its own resources in responding to underprivileged sectors of society is a primary concern, this poses greater demands on program developers in making sure that students are able to apply their research training in more meaningful ways amidst unique (and often times disempowering) political, social and material conditions. More importantly, educators entrusted with the research training of teachers must consider opening spaces for participation as these do not only present opportunities for knowledge production but also allow other 'voices' in this vast hierarchy of peripheral participation to be heard.

\section{REFERENCES}

Agarao-Fernandez, E. \& De Guzman, A. (2005). Contextual realities of teacher education in the Philippines. Educational Research for Policy and Practice, 4, 129-144.

Benesch, S. (2001). Critical English for academic purposes: Theory, politics and practice. Mahwah, New Jersey: Lawrence Erlbaum Associates.

Benesch, S. (1999). Rights analysis: Studying power relations in an academic setting. English for Specific Purposes, 18 (4), 313-327. Bloomaert, J. (2010). The sociolinguistics of globalization. Cambridge: Cambridge University Press.

Boylan, M. (2010). Ecologies of participation in school classroom. Teaching and Teacher Education, 26(1), 61-70 doi: 10.1016/j.tate. 2009.08.005

Burton, D. \& Bartlett, S. (2005). Practitioner research for teachers. London/ California: Paul Chapman Publishing. 
Calma, A. (2009). The context of research training in the Philippines: Some key areas and their implications. The Asia Pacific Education Researcher, 18 (2), 167-184.

Canagarajah, S. (1996). Non-discursive requirements in academic publishing, material resources of periphery scholars and the politics of knowledge production. Written Communication, 13(4), 435-472.

Carr, W., \& Kemmis, S. (1986). Becoming critical: Education, knowledge and action research. Brighton, Sussex: The Falmer Press.

Dick, B. (2006). Action research literature (2004-2006): Themes and trends. Action Research 4 (4), 439-458.

Foucault, M. (1977). Discipline and punish: The birth of the prison. London: Allen Lane.

Foucault, M. (1980). Power/knowledge: Selected interviews and other writings 1972-1977. London: Harvester.

Hagevik, R., Aydeniz, M., \& Rowell, C.G. (2012). Using action research in middle level teacher education to evaluate and deepen reflective practice. Teaching and Teacher Education, 28, 675-684.

Ho, D. (2013). Focus group. In The encyclopedia of applied linguistics. DOI: 10.1002/9781405198431.wbeal0418

Lave, J. \& Wenger, E. (1991) Situated learning: Legitimate peripheral participation. Cambridge: Cambridge University Press.

Man, J., Weinkauf, J., Tsang, M. \& Sin, D. (2004). Why do some countries more than others? An international comparison of research funding, English proficiency and publication output in highly ranked general medicine journals. European Journal of Epidemiology, 19 (8), 811-817.

Pearson, M. \& Brew, A. (2002). Research training and supervision development. Studies in Higher Education, 27 (2), 134-150.

Penney, D. \& Leggett, P. (2005). Connecting initial teacher education and continuing professional learning through action research and action learning. Action Learning: Research and Practice, 2 (2), 153-169.

Poon, A. (2008). How action research can complement formal language teacher education. Asia Pacific Education Researcher, 17 (1), 43-62. 
Salager-Meyer, F. (2008). Scientific Publishing in developing countries: Challenges for the future. English for Academic Purposes, 7, 121-132.

Strauss, A.L. \& Corbin, J. (1998). Basics of qualitative research: Techniques and procedures for developing grounded theory. Thousand Oaks, CA: Sage Publications.

Tupas, T.R.F. (2011). Afterword: Crossing cultures in an unequal global order: Voicing and agency in academic writing in English. In P. L. Ha \& B. Bahrain (Eds.). Voices, identities, negotiation and conflicts: Writing academic English across cultures. (pp.213-220). Bingley, UK: Emerald Publishing Group.

Uzuner, S. (2008). Multilingual scholars' participation in core/ global academic communities: A literature review. English for Academic Purposes, 7, 250-263.

Valdez, P. M. (2012). Actualizing critical English language teaching in the classroom: A Philippine experience. The Asia Pacific Education Researcher, 21(2), 279-285. 